\title{
The Causality and Relation of Corruption With Basic Macro-economic Tables (Charts) ${ }^{*}$
}

\author{
Bülent Özkan \\ Silkroad Development Agency, Gaziantep, Turkey \\ Birol Erkan \\ Kilis 7 Aralık University, Kilis, Turkey
}

\begin{abstract}
Corruption which means the use of public power for private interests is one of the most important problems either in less developed and developing countries or developed countries. Especially in less developed and developing countries, corruption is a serious obstacle in front of economic development. Corruption is raised from deficiency in democracy, deficient judgement, unfair elections and dependent media sector includes bribery, embezzlement, forgery, fraud, favouritism, nepotism and illegal beneficial use of public authority. The aim of the paper is to determine the causal relationship between corruption and basic macro-economic indicators. For this purpose, in this study, the basic macro-economic indications such as import, export, budget deficit, manufacturer price index are taken into account as variables to examine their relation with corruption. By getting use of the data obtained from CPI index, the relation between the variables is examined using the $T$-Test. Furthermore, to determine the causality among all the variables, correllation analysis is applied to present causal relations between the corruption and macro-economic variables. The findings concluded that there is a significant correlation among corruption, manufacturer price index and export-import. However, there is no significant correlation with budget deficit.
\end{abstract}

Keywords: corruption, import, export, budget

\section{The Concept of Corruption and Outbreak Causes of It}

In most parts of the world, corruption is one of the most important obstacles for development and especially has lately increased in international field. Most of the countries give priority to eliminating the corruptions in their development projects (URRA, 2007, p. 2). The corruption is a social, political and economic fact which is sophisticated and obtains in all of the countries on various forms and levels. Despite corruption exists both in public and private sectors, public opinion is more interested in the corruptions those happen in public sector.

There isn't a consensus of opinion in literature to define and to be conceived of the term corruption. In

\footnotetext{
* The first version of this article was presented in April 15-16, 2010, Turgut Özal International Conference on Economics and Politics-I "Global Crises and Economic Governance", Malatya, Turkey.

Bülent Özkan, Ph.D., Assistant Professor, Silkroad Development Agency.

Birol Erkan, Ph.D., Assistant Professor, Department of Marketing and Foreign Trade, Vocational High School, Kilis 7 Arallk University.

Correspondence concerning this article should be addressed to Birol Erkan, Mehmet Sanli Mah., Dogan Gures Pasa Bul., No.134, Kilis 7 Aralık University, Vocational High School, Kilis, Turkey. E-mail: birolerkan@kilis.edu.tr.
} 
literature; corruption is widely defined as, to abuse the public power for private interests as shown in Figure 1.

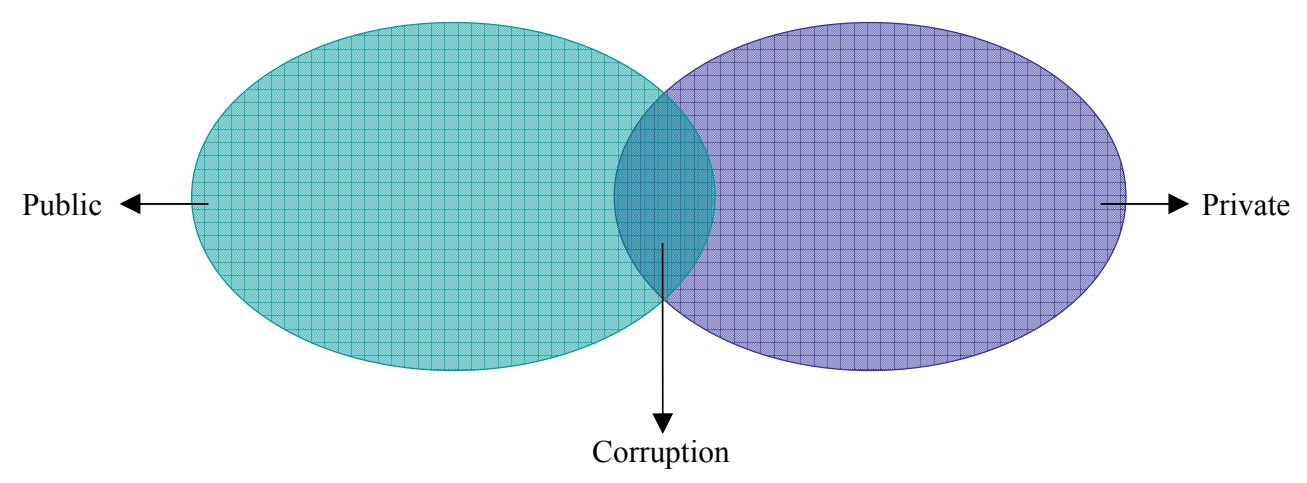

Figure 1. Corruption as the use of public power for private interests.

Many international study focused on the institutional factors below as the causes of corruption (BSOS, retreieved from http://www.bsos.umd.edu/gvpt/):

- Deficiency in democracy;

- Deficient judgment;

- Unfair elections;

- Dependent media sector.

The determinations below can be spotted if the countries, in which corruption happens densely and in which corruption happens rarely, are filtered in terms of various criteria.

First is that there is a very close correlation between corruptions and economic system. While, in the countries, in which corruption level is low, market economy is executed, and in the countries which corruption level is high, protectionism is executed. Also in these economically protective countries, bureaucracy is a common trouble. This bureaucracy exposes the opportunities for corruption and bribery. People, who face the obstacle of bureaucracy, necessarily try to finish up their processes by bribery or corruption. On the other hand, the budget of bureaucratic procedures causes a bribery market for the officers.

Another case is related to the democratization. Corruptions are more common in under-democratizated countries. There is a close correlation between democracy and transparent government. In fact, democracy is a regime of open society. Thus, in democratic countries, it is easier for corruptions coming into light and to be audited. On the other hand, in democratic countries, the principal of division of powers mainly operates functionally. So, one can urge the independency of judgment and effectiveness of the law system in democratic countries.

Corruption mainly falls out in listed forms below (Rohwer, 2009, p. 42):

- Bribery;

- Embezzlement;

- Forgery;

- Fraud;

- Favoritism;

- Nepotism;

- Illegal beneficial use of public authority. 
Corruption is classified into two as insignificant and significant:

(1) Insignificant corruption is an everyday situation. This situation comes into being while interaction of people with the low or medium positioned officials in hospitals, headquarters, or in other public institutions. Besides the amount of money transaction is little, it's an individual happening;

(2) Significant corruption is done in a vast scale and embraces a significant monetary transaction. It is used as synonym with political corruption.

According to the researches of Transparency International over corruption, the institutions which face to corruptions the most are listed in order below (Transparency International, 2009, p. 5):

- Political parties;

- Public corporations;

- Parliament;

- Private sector, enterprises;

- Judgement authorities;

- Media corporations.

It is not a compulsory, for those corruptions which form by an illegal beneficial use of public power, to have a monetary value. If these corruptions embrace a monetary value, then there is an accusation of bribery and so on which are defined in penal codes. Nevertheless, the diversion and illegal usage of the public authority to gain political social credit or psychologically self-satisfaction should be regarded as in the corruption concept (TOBB, 2000, pp. 114-115).

\section{Examples of the Studies on the Effects of Corruptions in Turkey}

In a study by Aktan (2001, pp. 129-141), relationships among economic liberalization, democracy and corruption were examined in developed and less developed countries, and it's expressed that widespread corruption in democracies has been blocked. It emphasized that democratization is not the only way for the prevention of corruption, but one of the most effective ways. However, it's indicated that corruptions reduce as the hegemony of state on economy is reduced.

In the study by Şalcı (2007, pp. 85-90), the importance of ensuring financial transparency is emphasized, and Turkey and Denmark were compared. Denmark's financial system has been shown as an example and fighting corruption has been pointed out as the most effective tool in ensuring transparency.

By the study of Bağdigen and Dökmen (2006, pp. 23-38), the relationship between corruption and public expenditure in Turkey between the year of 1982-2003 is examined with the method of least squares. According to the results obtained from the study, as the corruption perception index (CPI) decreases (corruption increases) level of public expenditure reduces, as the CPI increases (corruption decreases) public expenditure increases.

By the study of Ata (2009, pp. 1-309), what the opportunities and motivations which cause corruption are discussed by examining EU 25 countries. According to this result, an increase in GDP per capita increases CPI, an increase in inflation reduces CPI, increasing economical freedoms increases CPI and the increase in income inequality reduces CPI.

In the study by Bayar (2007, pp. 1-22), it aimed to reveal the possible causes of corruptions in Turkey. Contrary to expectations regression results revealed that Turkey's economic opening to global markets and going 
into the rapid growth period has increased corruptions.

In the study by Baldemir, İşçi and Görgülü (Retrieved from http://www.ekonometridernegi.org/bildiriler/o2s1.pdf), an application was made on the corruption in Turkey using the MIMIC model approach. Especially since 1985, unrestraint with economically opening to the foreign markets, clumsiness and size of public sector has increased the corruptions. Budget deficits and increasing public expenditure, have led to increased corruption.

In the study by Kutlar and Doğanoğlu (Retrieved from http://idari.cu.edu.tr/, 2010), the relationship among corruption, public investment and growth was examined in Turkey between the year of 1980-2000. Those expressed that corruptions had public investments increased, had a negative impact on public revenues and per capita income, had growth delayed and had investments unproductive.

In the study of Sayan and Kışlalı (Retrieved from www.todaie.gov.tr/ozetsy/1752.doc, 2010), 90 countries (including Turkey), in eight categories, 12 variables related to corruption were taken into account. According to the results obtained, as the public budget to GDP ratio increases, corruption decreases. The increasing level of education reduces corruption. Increasing income inequality and inflation increases corruption. However, countries' economies are whether opened or closed and the size of economy has no effect on the CPI.

\section{Examples of the Studies on the Effects of Corruptions in the World}

In the study by Naved and Shaid (2010, pp. 303-308), the impact of corruption in the financial sector performance in 38 developed and developing countries between 1995-2005 was examined. In the study in the regression model, domestic credit to the private sector was taken as a dependent variable. The perception index calculated by the Transparency International, per capita GDP and trade openness have been taken as an argument. According to the model, the increase in corruption perception index leads to an increase in domestic credit to the private sector. However, the increase in per capita GDP and trade openness also leads to an increase in domestic credit to the private sector.

In the study by Sarkar and Hasan (2001, pp. 111-116), the impact of the corruption perception index on the productivity of investment between the year 1986-1996 in 87 countries was examined. Sectoral resource allocation of investments is effected by positive in lowest levels of corruption (high CPI values) (the productivity of investment increases). The highest levels of corruption (low CPI values) is leading to disruptive effects on the allocation of investment resources (reduces the productivity of investment).

In the study made by Universitat Passau (GRAF, 2008, pp. 1-3), correlations between world corruption perception index in countries with per capita GDP, GDP, productivity and independancy of press were investigated. According to the results, as the countries' per capita GDP values decrease, corruption perception index values (CPI) also decreases (increased levels of corruption). In countries GDP per capita is very high such as Luxembourg and Norway, CPI values are also at a very high level (the level of corruption is very low). However, in countries with low CPI values, press independancy index values are low either.

In the study by Keller and Sik (2009, pp. 163-178), corruption levels were measured in Balkans, Baltic Region, Mediterranean, Central Europe, Scandinavia and Western European countries, by taking the average of the CPI values in 2006 and 2008. According to the results obtained, while the highest corruption (the lowest $\mathrm{CPI}$ ) values are being seen in Balkans (Romania, Bulgaria, Greece), Baltics (Latvia, Lithuania) and Central 
Europe (Poland, Czech Republic, Hungary) countries, lowest corruption (the highest CPI ) values are seen in Scandinavia (Denmark, Finland, Sweden) and Western European (Netherlands, Luxembourg) countries.

In the study made by Wilhelm (2002, pp. 177-189), the correlations among black market activities, business activities related to excessive, unnecessary restrictions and regulations and the CPI were measured, and strong and significant correlations among these variables were found out. The accuracy of three measures, has also provided high significant correlation with real GDP per capita and enhanced the size of the study. By the study, a very strong correlation between CPI and real GDP per capita has been determined and it has chosen that corruption constitutes as a serious obstacle for economic growth and development. At the same time, a negative correlation between CPI and black market activities was obtained. The higher CPI (corruption become less) black market activities are decreasing. However, there is a significant correlation (in the opposite direction) between excessive market regulations and CPI. As the CPI decreases (as corruptions increase) market restrictions have been increasing.

In the study by Ewers and Smith (2007, pp. 1-6), the correlation between environmental sustainability index (ESI) and corruption perception index (CPI) was examined. ESI is an index consisted of 76 different criterias such as environmental sustainability, natural resources, pollution levels, environmental management and community's development capacity of their environmental performance. According to these researchers, rich countries could allocate more resources to environmental policy and could be able to reduce environmental problems. However, it is also likely that the major economies and countries with high consumption of society to have low environmental sustainability than developing ones. Corruption has caused negative impact on air and water pollution. However, as a result of the analysis, both positive and negative correlation was found between corruption and environmental sustainability.

In the study made by Morse (2006, pp. 1-22), the correlation between the environmental sustainability index (ESI) which is organized by the World Economic Forum in the year 2000-2005 and the corruption perception index (CPI) which is organized by the Transparency International was analysed, considering 64 countries. The hypothesis that suggests of high-level corruption damages environmental sustainability was investigated. In case of corruption to increase, per capita GDP and the GDP will fall, it will result of environmental sustainability to decrease.

In the study by Tanz and Davoodi (Retrieved from http://www.imf.org/external/pubs/ft/wp/wp97139.pdf, 2010), corruption impact on public investment and growth was examined. According to the results obtained, the corruption increases public investment but reduces the efficiency of investment.

In the study by Pellegrini and Vujic (2007, pp. 1-14), the impact of corruption over income and environmental policies was investigated. It concluded that environmental protection policies would be affected by corruption through its impact on income.

In the study conducted over 58 countries by Bigdai (2002, pp. 1-10), the impact of globalization over bureaucratic corruption has been analysed. According to the findings, globalization has increased the elasticity of demand for public goods. Changes in demand will lead those who corrupt to review their behaviors. In a new case, it will maximize the benefits of public employees, reduce the amount of bribery and will begin to provide public goods to be used largely by the interests of the economy. As a result, the amount of public goods also increase. 
In the study made by Gheorge and Gheorge (Retrieved from http://steconomice.uoradea.ro/anale/volume/2008/, 2010), the correlation among CPI, economic freedom index, globalization index and macroeconomic variables was examined related to the 114 countries. It is remarkable that with the decrease in all three indices (bad governance), per capita GDP and economic growth figures fall. However, economic growth means less corruption, more globalization and economic freedom.

In the study made by Bryane and Linacre (2004, pp. 17-22), corruption and bribery in Turkey and in the new entrant countries to the EU are compared. Anti-corruption struggle holds the key for Turkey's EU accession and his future. Contrary to the claims, data show that the level of corruption between in Turkey and EU member countries is not a huge gap. Although Turkey has fulfilled many obligations for entry to the EU, he needs to strengthen anti-corruption programs.

\section{Measuring Corruption}

One of the most important issues related to the subject is whether it is possible or not, to measure the corruption, if possible, how is that. Corruption is a variable that cannot be measured directly. However, the number of indicators focused on the measurement of corruption, lately has increased exponentially.

Objective data concerning the measurement of corruption is difficult to obtain. In a country as well as the global level, exact calculation and measurement of the corruption still can not be done, because some corruption measurements cannot reflect the actual level of corruption. In other words, the current indicators of the actual level of corruption has been expressed in an incomplete manner.

However, in recent years with the perception researchs, corruption is measured at regional, national and global levels. The resulting data provide some possibilities such as the development of corruption, comparisons among countries, statistical analysis and correlation analysis according to different variables of corruption.

Today, the most important indicator to measure corruption is corruption perception index (CPI) that is published annually by the Transparency International (Transparency International (TI)).

The reason for calculation of corruption perception index regarding countries by Transparency International is the will for people to be aware of the happenings related to the issue, providing the statistical surveys to be performed, to encourage governments in the anti-corruption efforts in their countries (Soreide, 2006, pp. 1-2).

Corruption perception index (CPI) was published for the first time in 1995. Since then, Transparency International has to be the most important institution related to the gathering and distribution of information about corruption. CPI which is just one of the works of Transparency International related to the corruption, is the most important source to apply about the level of corruption in the countries.

Corruption perception index (CPI), is the work of a survey in which the international activities of the people working as managers in companies and perception of businessmen for corruption are reflected. Regarding the study at least four different surveys are done in each country, variance differences in the results are being tried to put forward by doing more than one survey (Aktan, 2001, p. 129). The index value obtained from each country those are research titles, has an index value located from 0 (the highest value of corruption) to 10 (the lowest value of corruption). Corruption perception index values, are listed from highest to lowest country by country by Transparency International. Results obtained are indicators for the levels of the public 
sector in which private profit rate observance, of embezzlement, forgery, bribery and fraud (Eigen, 2010).

Corruption perception index, which is used by Transparency International to measure the level of corruption in the countries is not the only variable. Furthermore for measurement of corruption, bribe payers index (BPE) and the global corruption barometer (GCB) are also used. Bribe payers index is obtained by the views of businessmen and operators on corruption and bribery issues. While global corruption barometer measures public opinion about corruption, corruption perception index focuses on reputable businessmen's and expert's opinions about corruption. However, while GCB deals with small (individual) corruption, CPI involves corruption in the public sector and policies (significant corruption). Despite their differences, there has been a significant correlation between the two studies (FAQ, 2007, p. 3).

The most recent study by Transparency International related to corruption perception index has done for the year 2009. 2009 CPI conducted by 10 independent institutions is based on 13 different polls and research. In research related to 180 countries, three countries having respectively high CPI value (the lowest corruption), are in order New Zealand (CPI = 9.4), Denmark (CPI = 9.3) and Singapore (CPI = 9.2) (TI, 2009, pp. 1-4). However, it is a dramatic case that Singapore is the third. The country which has the lowest CPI value (highest corruption) is Somalia (CPI = 1.1). Among 180 countries for only 49's CPI index is 5 or above (Retrieved from http://www.gizmac.com/transparency-international-2009-corruption-perceptions-index/13375/, 2010).

\section{Deficits of the Corruption Perception Index}

The relationship among the index values from 0 to 10 is not so obvious (Soreide, 2006, p. 3). For example, for the corruption in the 6th country, it cannot be said how many times more than the 3rd country, and only can make comments about that with more corruption in that country. However, interpretation of the dynamic size of the index is difficult as well. If, in any year, CPI value of $X$ country is lower than the one in $Y$ country, then next year when the CPI value of $X$ passes the value of $Y$ country, then it is not obvious if the corruption level of $X$ country reduced or corruption level of $Y$ increased. These questions are very hard to answer.

CPI should make the political conflicts, investment decisions and academic researches productive. However, the perception poses a problem in measurement of corruption by general opinion. The experts' interest in this issue emphasize that the data related to the perception is inadequate. Indeed, the accurate data can be requested from the actors who always research corruption and control issues. This type of information is scarce, and this information is hard to reach. Therefore, recent researches show that a serious difference has been between corruption perception index and the real corruption (Urra, 2007, p. 6). As the data collected relates to perceptions rather than to real phenomena, it has to be considered whether such perceptions improve our understanding of what real levels of corruption may be (Lambsdorff, 1998, p. 5).

\section{Eradicating Corruption}

The success of corruption prevention programs depends on of the following conditions which are indispensable (IDLO, 2006, pp. 1-2):

- Fighting economic inequality;

- To provide equality by social welfare programs;

- Policy changes;

- New legislations of the interests of preventing corruption; 
- Strengthening of laws in force;

- Increasing public audit (BSOS, Retrieved from http://www.bsos.umd.edu/gvpt/, 2010);

- A strong parliamentary management;

- Well-performanced judgement system;

- Independent and honest anti-corruption units;

- Government's transparency in budget, income and financial flows;

- Independent media;

- Active civil society (Transparency International, 2009, p. 1);

- Public and private sector cooperation.

\section{The Relationship Between Macroeconomic Indicators and Corruption: The Case of Turkey}

Increase in corruption, also in terms of macro economic indicators, lays out a threatening situation. Because, in the country corruption increases, the macro-economic indicators will also begin to deteriorate; impoverishment trend will begin to emerge in the country. When the corruption perception index values were examined, it can be seen that in the countries whose corruption perception index (CPI) is low (poverty is high) macro-economic indicators are pointing out poverty.

Increase of corruptions (decrease of CPI) (Bigdai, 2002, p. 2):

- Causes economic growth to slow down;

- Causes physical investments to decrease;

- Discourages investment in human capital;

- Reduces the productivity of the economy;

- Makes allocation of resources inefficient;

- Reduces the tax liability and awareness and discourages the tax-pay-willing of society;

- Causes the reduction of public revenues;

- Bellows inflation;

- Limits the ability of government to put adequate quality of public services;

- Will reduce the credibility indexes of government (Konar, 2009, p. 89);

- Affects the macro economy adversely by raising index of deviation from the policies;

- Sustainability index falls;

- Obstacles economic development (Transparency International, 2009, p. 4);

- Lead to inequity in income distribution.

According to the results of corruption perception index performed each year by Transparency International, in 2009 Turkey and Cuba together shared the rank 61 among 180 countries in the survey $(\mathrm{CPI}=4.4)$. This data was obtained by the results of seven researches. During researches local and foreign experts', businessmen's and country analysts' comments have been applied. In mentioned investigations, ratings were made according to corruption in the country, frequency of occurrence regardless of the size, occurence fields and questions like whether this situation creates difficulties in doing business in that country. Looking at the index results, Turkey's index value is at the half level of those countries' whose corruption perception index values are less and quite in a position where failure can be expressed. 
Also can be seen in Table 1 and Figure 1 (Transparency International, Retrieved from http://www.transparency.org, 2010), in Turkey, according to the CPI for the year in a general sense of instability may be mentioned. However, especially after 2003, emerged from relative improvement and consistent appearance is remarkable.

Table 1

Corruption Perception Index (CPI) Values in Turkey Between the Years 1995-2009

\begin{tabular}{lllllllllllllll}
\hline 1995 & 1996 & 1997 & 1998 & 1999 & 2000 & 2001 & 2002 & 2003 & 2004 & 2005 & 2006 & 2007 & 2008 & 2009 \\
\hline 4.1 & 3.5 & 3.2 & 3.4 & 3.6 & 3.8 & 3.6 & 3.2 & 3.1 & 3.2 & 3.5 & 3.8 & 4.1 & 4.6 & 4.4 \\
\hline
\end{tabular}

Note. Data obtained from http://www.transparency.org, and it was organized by the authors.



Figure 1. CPI values in Turkey (1995-2009).

Despite the reforms which have been put in Turkey's agenda in recent years and legislation efforts in the framework of the compliance programme to European Union have made a contribution to its country index relatively, Turkey still has major shortcomings for implementation title (Transparency Society, 2008, p. 2).

As a result, in Turkey the issues of completion of the legislation to increase transparency and minimize corruption, implementation of that legislation, necessary mechanisms to ensure complete applications and the establishing institutions, still maintain its importance and to be the priority.

In Table 2, besides CPI indexes of Turkey by years, chosen macro-economic variables such as manufacturer price index (MPI), export-import values and budget deficits values has been presented. Despite the inconsistency of CPI values among the years 1995-2003, as of 2003 this inconsistency has improved. Similarly MPI values fluctuate between the years 1995-2003. But thanks to the rigid policies operated after the $2001 \mathrm{crisis}$, MPI values have laid out a descending and promising trend. Also the export and import values have shown an advance by years, but by the crisis faced in 2009 , a sharp decrease has been seen. 
Table 2

Chosen Macro-economic Variables by Years (1995-2009)

\begin{tabular}{lrrrrr}
\hline Year & MPI & Exports & Imports & Budget deficit & CPI \\
\hline 1995 & 65.60 & $21,637,040$ & $35,709,011$ & 315 & 4.1 \\
1996 & 84.90 & $23,224,465$ & $43,626,642$ & $1,233,350$ & 3.5 \\
1997 & 91.00 & $26,261,072$ & $48,558,721$ & $2,235,153$ & 3.2 \\
1998 & 54.30 & $26,973,952$ & $45,921,392$ & $3,803,376$ & 3.4 \\
1999 & 62.90 & $26,587,225$ & $40,671,272$ & $9,151,620$ & 3.6 \\
2000 & 32.70 & $27,774,906$ & $54,502,821$ & $13,264,885$ & 3.8 \\
2001 & 88.60 & $31,334,216$ & $41,399,083$ & $29,036,095$ & 3.6 \\
2002 & 30.80 & $36,059,089$ & $51,553,797$ & $40,090,026$ & 3.2 \\
2003 & 13.90 & $47,252,836$ & $69,339,692$ & $40,204,415$ & 3.1 \\
2004 & 13.80 & $63,167,153$ & $97,539,766$ & $30,300,001$ & 3.2 \\
2005 & 12.66 & $73,476,408$ & $116,774,151$ & $8,116,629$ & 3.5 \\
2006 & 11.58 & $85,534,676$ & $139,576,174$ & $5,768,293$ & 3.8 \\
2007 & 5.94 & $107,271,750$ & $170,062,715$ & $14,491,205$ & 4.1 \\
2008 & 8.11 & $132,027,196$ & $201,963,574$ & $17,589,195$ & 4.6 \\
2009 & 6.43 & $102,165,000$ & $140,775,000$ & $52,630,007$ & 4.4 \\
\hline
\end{tabular}

Note. Data obtained from http://www.tuik.gov.tr and was organized by the authors.

\section{Findings of Research}

Table 3

Correlation Indexes

\begin{tabular}{|c|c|c|c|c|c|c|c|}
\hline & & Years & MPI & Export & Import & Deficit & CPI \\
\hline \multirow[t]{3}{*}{ Years } & Pearson Correlation & 1 & $-0.852\left(^{* *}\right)$ & $0.916\left(^{* *}\right)$ & $0.885\left(^{* *}\right)$ & $0.555\left(^{*}\right)$ & 0.447 \\
\hline & Sig. (2-tailed) & & 0.000 & 0.000 & 0.000 & 0.032 & 0.095 \\
\hline & $\mathrm{N}$ & 15 & 15 & 15 & 15 & 15 & 15 \\
\hline \multirow[t]{3}{*}{ MPI } & Pearson Correlation & $-0.852\left(^{* *}\right)$ & 1 & $-0.770\left(^{* *}\right)$ & $-0.765\left(^{* *}\right)$ & -0.425 & -0.307 \\
\hline & Sig. (2-tailed) & 0.000 & & 0.001 & 0.001 & 0.114 & 0.266 \\
\hline & $\mathrm{N}$ & 15 & 15 & 15 & 15 & 15 & 15 \\
\hline \multirow[t]{3}{*}{ Export } & Pearson Correlation & $0.916\left(^{* *}\right)$ & $-0.770\left(^{* *}\right)$ & 1 & $0.992\left(^{* *}\right)$ & 0.293 & $0.649\left(^{* *}\right)$ \\
\hline & Sig. (2-tailed) & 0.000 & 0.001 & & 0.000 & 0.290 & 0.009 \\
\hline & $\mathrm{N}$ & 15 & 15 & 15 & 15 & 15 & 15 \\
\hline \multirow[t]{3}{*}{ Import } & Pearson Correlation & $0.885\left(^{* *}\right)$ & $-0.765\left(^{* *}\right)$ & $0.992\left(^{* *}\right)$ & 1 & 0.193 & $0.639\left(^{*}\right)$ \\
\hline & Sig. (2-tailed) & 0.000 & 0.001 & 0.000 & & 0.491 & 0.010 \\
\hline & $\mathrm{N}$ & 15 & 15 & 15 & 15 & 15 & 15 \\
\hline \multirow[t]{3}{*}{ Deficit } & Pearson Correlation & $0.555\left(^{*}\right)$ & -0.425 & 0.293 & 0.193 & 1 & 0.002 \\
\hline & Sig. (2-tailed) & 0.032 & 0.114 & 0.290 & 0.491 & & 0.993 \\
\hline & $\mathrm{N}$ & 15 & 15 & 15 & 15 & 15 & 15 \\
\hline \multirow[t]{3}{*}{ CPI } & Pearson Correlation & 0.447 & -0.307 & $0.649\left(^{* *}\right)$ & $0.639\left(^{*}\right)$ & 0.002 & 1 \\
\hline & Sig. (2-tailed) & 0.095 & 0.266 & 0.009 & 0.010 & 0.993 & \\
\hline & $\mathrm{N}$ & 15 & 15 & 15 & 15 & 15 & 15 \\
\hline
\end{tabular}

Notes. ${ }^{* *}$ Correlation is significant at the 0.01 level (2-tailed); ${ }^{*}$ Correlation is significant at the 0.05 level (2-tailed). 
First, the correlation analyses have been applied to the findings of research to classify the variables group that wasn't subject to any classification and determined by the researcher also by using the literature.

One can bring out from the Table 3, while there is a significant correlation among CPI, MPI and export-import, there is no significant correlation with deficit. According to this, in the years corruption is high, there is a setback for inflation. Similarly in the phases corruption and degeneration are at high levels, there is an inconsistency and setback for import and export values. In these phases firms try to hide their profits by underground economy.

The lack of a relation between CPI values and deficit according to the correlation results is because of the changing of public expenditure and revenues due to economy policies. Governments take new measures in order to avoid crisis and unexpected happenings in economy. And this affects the balance of the budgets adversely.

\section{Conclusion}

In this study, the correlation between corruption perception index and chosen macro economic variables has been determined. The corruption issue is complicated and should be analysed by each way, that's why the correlation between corruption and just these variables has been analysed.

As a result, when the effects of corruption over chosen macro economic variables have been analysed, one can find that corruption has a significant effect on inflation and foreign trade data, and has no effect on the budget deficits. The analyses orientated to test the correlation scale to be reliability and proof, show that the prepared measuring tool is acceptable to measure the effect of corruption over the macro-economic variables.

\section{References}

Aktan, C. C. (2001). Yolsuzluklar ile Ekonomide Serbestleşme ve Demokratikleşme Arasındaki İlişki. Yolsuzlukla Mücadele Stratejileri, 129-141.

Ata, A.Y., (2009). Kurumsal İktisat Çerçevesinde Yolsuzluğun Fırsat ve Motivasyonları: AB Ülkeleri Üzerine Bir İnceleme, Yayınlanmamış Doktora Tezi-Çukurova Üniversitesi SBE İktisat ABD.

Bağdigen, M., \& Dökmen, G., (2006). Yolsuzluklarla Kamu Harcamaları Arasındaki İlişkinin Ampirik Bir Analizi: Türkiye Örneği. ZKÜ Sosyal Bilimler Dergisi, 2(4), 23-38.

Baldemir, E., İşçi, Ö., \& Görgülü, H. (2010). MIMIC Model ve Yolsuzluk Üzerine Türkiye Uygulaması. Retrieved from http://www.ekonometridernegi.org/bildiriler/o2s1.pdf

Bayar, G., (2007). Türkiye'de Yolsuzluğun Nedenleri-Ekonometrik Bir İnceleme. Türkiye Ekonomi Kurumu, Tartışma Metni $2007 / 3,1-22$.

Bigdai, V. (2002). Globalization and corruption. One Brookings Drive, 1-10.

Bryane, M., \& Linacre, C. (2004). The Role of Anti-Corruption in the Turkish Accession to the European Union. Turkish Policy Quarterly, 3(4), 17-22.

BSOS. (2010). The roots of corruption. Retrieved from http://www.bsos.umd.edu/gvpt/

Eigen, P. (2010). Corruption is a major cause of poverty as well as a barrier to overcoming it, zero tolerance for corruption. The Corruption Perceptions Index \& White-Collar Crime, Part 4. Retrieved from http://www.anticorruption.info

Ewers, R. M., \& Smith, R. J. (2007). Choice of index determines the relationship between corruption and environmental sustainability (E \& S). Ecology and Society, 12(1), 1-6.

FAQ. (2007). TI Global Corruption Barometer, 1-3.

Gheorge, S., \& Gheorge, C. (2010). Economic freedom, globalization, corruption and macroeconomic results. Retrieved from http://steconomice.uoradea.ro/anale/volume/2008/

Graf, J. (2008). Complies the 14th Corruption Perceptions Index (CPI) on Behalf of Transparency International (TI). Universitat Passau Chair in Economic Theory, 1-3.

IDLO. (2006). Anti-corruption: A capacity building approach. Development Law Update (DLU), 7, 1-2. 
Johann, G. (2010). Transparency international (TI) 1998 corruption perceptions index-framework document. Retrieved from http://www.icgg.org/downloads/FD1998.pdf

Keller, T., \& Sik, E. (2009). The perception, the tolerance, and the practice of corruption. Tarki European Social Report, 163-178.

Konar, A. K. (2009). A paradox of corporate perception and perpetuation of corruption. Journal of Social Sciences, 18(2), 81-93.

Kutlar, A,. \& Doğanoğlu, F. (2010). Türkiye’de 1980 Sonrası Yolsuzluklar, Kamu Yatırımları ve Büyüme Üzerine Bir Ekonometrik Çalışma. Retrieved from http://idari.cu.edu.tr/

Morse, S. (2006). Is corruption bad for environmental sustainability? A cross-country analysis. Ecology and Society, 11(1), 1-22.

Naved, A., \& Shahid, A. (2010). Corruption and financial sector performance: A cross-country analysis. Economics Bulletin, 30(1), 303-308.

Pellegrini, L., \& Vujic, S. (2003). Corruption, economic development and environmental policy. European Summer School, Institute for Environmental Studies-IVM, 1-14.

Rohwer, A. (2009). Measuring Corruption: A comparison between the transparency international's corruption perceptions index and the world bank's worldwide governance indicators. CESifo DICE Report, 3, 42.

Şalci, F. (2007). Türkiye'nin Dünya Mali Saydamlık Sıralamasında Yeri ve Mali Saydamlığa Ulaşmış Bir Ülke: Danimarka. Bütçe Dünyası, 2(26), 85-90.

Sarkar, H., \& Hasan, M. A. (2001). Impact of the efficiency of investment: Evidence from a cross-country analysis. Asis-Pacific Development Journal, 8(2), 111-116.

Sayan, İ. Ö., \& Kişlali, M. (2010). Yolsuzluk Üzerine Ekonometrik Bir Çalışma. Amme İdaresi Dergisi, 37(2). Retrieved from http://www.todaie.gov.tr/ozetsy/1752.doc

Şeffaflik, D. (2010). Türkiye'nin şeffafliğa olan özlemi sürüyor. Retrieved from http://www.seffaflik.org

Soreide, T. (2006). Is it wrong to rank? A critical assessment of corruption indices. CMI Working Papers 2006/1, 1-13.

Tanzi, V., \& Davoodi, H. (2010). Corruption, Public Investment and Growth. IMF Working Paper. Retrieved from http://www.imf.org/external/pubs/ft/wp/wp97139.pdf

TOBB. (2000). Avrupa Birliği’ne Tam Üyelik Sürecinde Türkiye'de Yönetimin Yeniden Yapılanması. TOBB Yayınları, 114-115.

Transparency International. (2010a). Corruption perceptions index 2009. Retrieved from http://www.transparency.org/policy_research/surveys_indices/cpi/2009/

Transparency International. (2010b). Global corruption barometer 2009. Retrieved from http://www.transparency.org.

Transparency International. (2010c). Transparency in Reporting on Anti-Corruption, A Report on Corporate Practices. Retrieved from http://www.transparency.org

Transparency International. (2010d). What is new in the 2009 corruption perceptions index. Retrieved from http://www.transparency.org/policy_research/

Urra, J. (2007). Assessing corruption an analytical review of corruption measurement and its problems: Perception, error and utility. Edmund A. Walsh School of Foreign Service, 2.

Wilhelm, P. G. (2002). International validation of the corruption perceptions index: Implications for business ethics and entrepreneurship education. Journal of Business Ethics, 35(3), 177-189. 